\title{
A Development of Knowledge Management Model by ICT of Elder Community in Thailand
}

\author{
Surapon Boonlue
}

\begin{abstract}
This research aimed to 1) study and develop a model of knowledge management by ICT for elder community in Thailand, 2) study the implementation of a model of knowledge management by ICT for elder community, 3) approve the knowledge management model by ICT for elder community. The population was elder community of 14,246 people in 50 District of Bangkok, Bangkok. The 20 samples were elder community from group 5, Wat Panurangsi community, derived from cluster sampling. The research findings were that 1 ) the model of knowledge management by ICT for elder community in Thailand had 4 stages: Socialization, Externalization, Combination, and Internalization. There were 11steps, and 4 characteristics of using media. 2) The implementation results of the model of knowledge management by ICT for elder community in Thailand were as follow: 2.1 the learning achievement of health care of elder community in Thailand was significantly higher than before implementing the model at the level of $.01 .(t$-test $=$ 13.03 ). 2.2 the behavior on health care of elder community was significantly higher than before implementing the model at the level of .05 ( $t$-test=18.29) 2.3 the elder satisfied the knowledge management model by ICT for elder community in Thailand at the level of "most" $($ mean $=4.55$, S.D. $=0.56)$ and 3$)$ the experts agreed and approved the model of knowledge management by ICT for elder community in Thailand.
\end{abstract}

Index Terms-Knowledge management model, by ICT, elder community.

\section{INTRODUCTION}

The elder community in the world is total increasing due to the decrease of birth rate of population and Thailand is a same the other Country in the world. The change of economic, social, and technology including the progress of medical technology leads to the long life of population. Since 2005, the Thai society changes to aging society. The data from national statistical office in the year 2014 found that the ratio of elder was rapidly increasing. The survey in 2013, the amount of elder in Thailand was at $14.9 \%$ of the population whereas in 2011 the amount of elder in Thailand was at $12.2 \%$. The tendency of increasing amount of elder was continually higher and the elder will live alone [1]. The social problem of increasing elder leads to the other problem such as the problem of hygiene, the physical status of people is deteriorated, lack of taking care of health and also lacking of people to take care. These problems often occurred with the city society. Even the country society might not chance so

Manuscript received October 26, 2016; revised March 23, 2017.

Surapon Boonlue is with the Department of Educational Communications and Technology, Faculty of Industrial Education and Technology, King Mongkut's University of Technology Thonburi 126 Pracha Uthit Rd., Thung Khru, Bangkok 10140, Thailand (e-mail: surapon.boo@kmutt.ac.th). much but also not different at the end of life. Relatives and friends in the same age were the community to help the elder happy and meaningfully live in society. Activities in elder community helped the elder don't feel lonesome. In the community, there were elder or old age people to take care and access the basic service, especially the elder in the country [2].

At present, livelihood in the information technology age in terms of virtual society makes people use it for communication, even the elder. At the same time, the knowledge or information is presented via online media and social media. The information is both true and false. The information presented might be distorted. Some of the information in the social media which is mistake is shared without inspection. The use of information technology or social media should be suited to the work and the elder should be able to use information technology correctly and instead the social interaction in person. Some elder is not convenient to meet others to do some activities together, even in normal society. So the online community using information technology is not enough for knowledge management. So it is the best way for elder community to integrate technology in new age society to gain sustainable community that is similar to the normal society. Knowledge inquiring, storing and exchanging will help the social strong. The elder will be able to take care of themselves and be self-reliant. Knowledge management will make a process of knowledge management in health care. ICT is used as a tool for accessing knowledge, information and learn as much as others. The elder in country or in the city can also use technology [3].

\section{OBJECTIVES}

1) to study and develop a model of knowledge management by ICT for elder community in Thailand

2) to study the implementation of a model of knowledge management by ICT for elder community

3) to approve the knowledge management model by ICT for elder community

\section{SAMPLES}

\section{A. Population}

The population was elder community of 14,246 people in 50 District of Bangkok.

\section{B. Samples}

The 30 samples were elder community from group 5, Wat Panurangsi community, derived from cluster sampling. 


\section{RESEARCH INSTRUMENTS}

1) Survey form of using media, a synthesized form of model, achievement test for knowledge management, evaluation form of satisfaction, and evaluation form of acceptance

2) Instructional media on health care for elder community

- ICT for communication

- Health care

- Exercise for elder

3) Plan of knowledge management, application, Info-graphic media, social media (Facebook), website, Line application.

\section{RESEARCH METHOD}

The research was manipulated into 3 stages:

Stage 1 - A study and development of model knowledge management by ICT for elder community in Thailand

Stage 2 - An implementation of knowledge management by ICT for elder community in Thailand

Stage 3 - The acceptance of experts in knowledge management by ICT for elder community in Thailand

\section{RESEARCH FINDINGS}

Stage 1 - A study and development of knowledge management by ICT for elder community in Thailand. The survey results of using application in knowledge management by ICT for elder community in Thailand and model of knowledge management for elder community were as follow:

1) Most of samples were female at $93.33 \%$ and male at $6.67 \%$.

2) Most age of samples were between 60-70 years old at $70 \%$ and the less is between $71-80$ at $30 \%$.

3) The status of living with family was at $73.33 \%$ and the less live alone at $26.67 \%$.

4) The elder had knowledge of health care about taking care of health at the level of "average" at $63.33 \%$, the level of "most" at $16.67 \%$, the level of "much" at $13.33 \%$, the level of "little" at $6.67 \%$.

5) The attention to take care of health of the samples were at the level of "much" at $46.67 \%$, at the level of "most" at $33.33 \%$, at the level of "average" at $10 \%$, at the level of "little" at $6.67 \%$, and the level of "least" at $3.33 \%$.

6) The percentage of communication channel, the samples used "Line application" at the level of "most" at $66.67 \%$, the less was telephone at $26.67 \%$.

7) The percentage of equipment used for communication, most of the samples used mobile phone at $70 \%$.

8) The percentage of internet used was mostly between 8.00-11.00 a.m. (Morning) at 26.67\%.

9) The synthesize of information for knowledge management was from other country and comparing with information of knowledge management in Thailand [4].

10) The SECI Model for Knowledge Management composed of 4 main steps and 11 sub - steps, and 4 characteristics of using ICT.

From Fig. 1, The SECI Model to was developed for knowledge management by ICT, composed of 4 main steps:
1) S: Socialization - The first step of knowledge management, the members in community should gather and use ICT for the same purpose. The members came and meet to feel for doing cooperation.

TABLE I: THE SYNTHESIZE OF INFORMATION FOR KNOWLEDGE MANAGEMENT WAS FROM OTHER COUNTRY AND COMPARING WITH INFORMATION OF KNOWLEDGE MANAGEMENT IN THAILAND

\begin{tabular}{|c|c|c|}
\hline \multicolumn{2}{|c|}{ Theory of knowledge management (components) } & \multirow{2}{*}{$\begin{array}{l}\text { Knowledge } \\
\text { management } \\
\text { components by } \\
\text { synthesis }\end{array}$} \\
\hline $\begin{array}{l}\text { Nonaka \& Takeuchi, } \\
\text { (2000) }\end{array}$ & Vijarn Panit, (2005) & \\
\hline $\begin{array}{l}\text { (1)Create knowledge } \\
\text { vision }\end{array}$ & $\begin{array}{l}\text { (1)Create knowledge } \\
\text { vision }\end{array}$ & $\begin{array}{l}\text { (1)Create } \\
\text { knowledge vision }\end{array}$ \\
\hline $\begin{array}{l}\text { (2) Create knowledge } \\
\text { management team }\end{array}$ & $\begin{array}{l}\text { (2) Create knowledge } \\
\text { management team of } \\
\text { organization }\end{array}$ & $\begin{array}{l}\text { (2) Create } \\
\text { knowledge } \\
\text { management team }\end{array}$ \\
\hline \multicolumn{2}{|c|}{$\begin{array}{c}\begin{array}{c}\text { Theory of knowledge management } \\
\text { (components) }\end{array} \\
\end{array}$} & \multirow{2}{*}{$\begin{array}{l}\text { Knowledge } \\
\text { management } \\
\text { components by } \\
\text { synthesis }\end{array}$} \\
\hline \multirow[t]{2}{*}{$\begin{array}{c}\text { Nonaka \& Takeuchi, } \\
(2000)\end{array}$} & Vijarn Panit, (2005) & \\
\hline & $\begin{array}{l}\text { (3)Start from existing } \\
\text { intelligence or those } \\
\text { easily found from the } \\
\text { outside }\end{array}$ & $\begin{array}{l}\text { (3)Start from existing } \\
\text { intelligence or those } \\
\text { easily found from the } \\
\text { outside }\end{array}$ \\
\hline $\begin{array}{l}\text { (3)Create intense } \\
\text { knowledge } \\
\text { exchange } \\
\text { atmosphere for } \\
\text { lower level } \\
\text { personnel }\end{array}$ & $\begin{array}{l}\text { (4)Create intense } \\
\text { knowledge exchange } \\
\text { atmosphere for lower } \\
\text { level personnel }\end{array}$ & $\begin{array}{l}\text { (4)Create intense } \\
\text { knowledge exchange } \\
\text { atmosphere for lower } \\
\text { level personnel }\end{array}$ \\
\hline $\begin{array}{l}\text { (5)Emphasize on } \\
\text { organization } \\
\text { management of } \\
\text { "middle-up-down } \\
\text { management }\end{array}$ & $\begin{array}{l}\text { (6)Emphasize on } \\
\text { organization } \\
\text { management of } \\
\text { "middle-up-down } \\
\text { management }\end{array}$ & $\begin{array}{l}\text { (6)Emphasize on } \\
\text { organization } \\
\text { management of } \\
\text { "middle-up-down } \\
\text { management }\end{array}$ \\
\hline $\begin{array}{l}\text { (6)Change the } \\
\text { organization to } \\
\text { hypertext }\end{array}$ & $\begin{array}{l}\text { (7)Change the } \\
\text { organization to } \\
\text { hypertext }\end{array}$ & $\begin{array}{l}\text { (7)Change the } \\
\text { organization to } \\
\text { hypertext }\end{array}$ \\
\hline \multirow[t]{4}{*}{$\begin{array}{l}\text { (7)Create the } \\
\text { knowledge network } \\
\text { with outside world }\end{array}$} & $\begin{array}{l}\text { (8)Create the } \\
\text { knowledge network } \\
\text { with outside world }\end{array}$ & $\begin{array}{l}\text { (8)Create the } \\
\text { knowledge network } \\
\text { with outside world }\end{array}$ \\
\hline & $\begin{array}{l}\text { (9)Create horizontal } \\
\text { culture of independent } \\
\text { communication in } \\
\text { every direction }\end{array}$ & $\begin{array}{l}\text { (9)Create horizontal } \\
\text { culture of independent } \\
\text { communication in } \\
\text { every direction }\end{array}$ \\
\hline & $\begin{array}{l}\text { (10)Create recording } \\
\text { culture }\end{array}$ & $\begin{array}{l}\text { (10)Create recording } \\
\text { culture }\end{array}$ \\
\hline & $\begin{array}{l}\text { (11)Evaluate the } \\
\text { knowledge } \\
\text { management operation } \\
\text { result }\end{array}$ & $\begin{array}{l}\text { (11)Evaluate the } \\
\text { knowledge } \\
\text { management } \\
\text { operation result }\end{array}$ \\
\hline
\end{tabular}

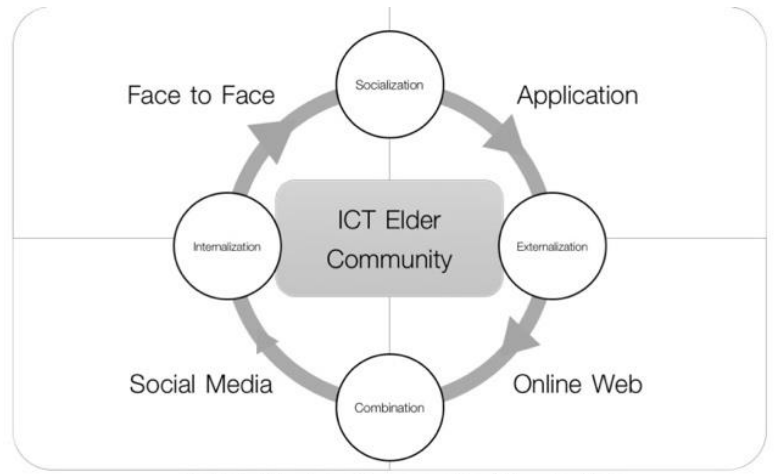

Fig. 1. The SECI model for knowledge management by ICT.

2) Externalization - The second step of knowledge management, the members of the community express the interesting issue and open mind to know each other in social network. The members connected to the network 
to download application for communication among members. The members shared knowledge in letters and share experience or knowledge for others.

3) C: Combination - The third step of knowledge management, the members of community learn the content by chatting and discuss, ask or appoint to do activities among members. The members collected knowledge, analyzed, discussed and summarized for explicit knowledge systematically.

4) I: Internalization - The last step of knowledge management, the members of community had passed the knowledge management and record knowledge got from the activities. The knowledge from KM activities can be used in practical for all.

The 4 main steps of knowledge management and 11 sub-steps:

TABLE II: THE 4 MAIN STEPS OF KNOWLEDGE MANAGEMENT AND 11 SuB-STEPS

\begin{tabular}{|c|c|c|c|}
\hline Main step & Sub - step & Activities & Media \\
\hline \multirow{2}{*}{ Socialization } & (1) Create knowledge vision & Gathering, meeting & $\begin{array}{l}\text { Face to Face ICT, } \\
\text { Application ,Facebook,Line }\end{array}$ \\
\hline & (2) Create knowledge management team & Identify the duty, assign & Application \\
\hline \multirow{4}{*}{ Externalization } & $\begin{array}{l}\text { (3) Start from existing intelligence or those } \\
\text { easily found from the outside }\end{array}$ & $\begin{array}{l}\text { Using ICT for learning } \\
\text { Health care of elder } \\
\text { Exercise }\end{array}$ & website \\
\hline & $\begin{array}{l}\text { (4) Create intense knowledge exchange } \\
\text { atmosphere for lower level personnel }\end{array}$ & $\begin{array}{l}\text { Study variety of content } \\
\text { Formats of instructional media }\end{array}$ & $\begin{array}{l}\text { Face to Face, } \\
\text { website } \\
\text { Application ,Facebook,Line }\end{array}$ \\
\hline & $\begin{array}{l}\text { (5) Manage the knowledge along with goods } \\
\text { development activity or new work format } \\
\text { development }\end{array}$ & $\begin{array}{l}\text { Identify the activities among } \\
\text { members }\end{array}$ & $\begin{array}{l}\text { Face to Face Practice ICT, } \\
\text { Application, ineFacebook, L }\end{array}$ \\
\hline & $\begin{array}{l}\text { (6) Emphasize on organization management of } \\
\text { "middle-up-down management }\end{array}$ & Appointment for exercise & $\begin{array}{l}\text { Face to Face } \\
\text { Application ,Facebook,Line }\end{array}$ \\
\hline \multirow{3}{*}{ Combination } & (7) Change the organization to hypertext & $\begin{array}{l}\text { Members are equal and connected } \\
\text { to new learning resources to use for } \\
\text { knowledge management }\end{array}$ & $\begin{array}{l}\text { Face to Face } \\
\text { Application ,Facebook,Line }\end{array}$ \\
\hline & $\begin{array}{l}\text { (8) Create the knowledge network with outside } \\
\text { world }\end{array}$ & $\begin{array}{l}\text { Knowledge inspection } \\
\text { Knowledge asset }\end{array}$ & Application ,Facebook,Line \\
\hline & $\begin{array}{l}\text { (9) Create horizontal culture of independent } \\
\text { communication in every direction }\end{array}$ & $\begin{array}{l}\text { Check before post in social media } \\
\text { And confirmable }\end{array}$ & Application ,Facebook,Line \\
\hline \multirow{2}{*}{ Internalization } & (10) Create recording culture & Evaluate the products & $\begin{array}{l}\text { Meeting, chatting } \\
\text { Application ,Facebook,Line }\end{array}$ \\
\hline & $\begin{array}{l}\text { (11) Evaluate the knowledge management } \\
\text { operation result }\end{array}$ & Evaluation together & Meeting, chatting \\
\hline
\end{tabular}

Stage 2 - An implementation of knowledge management for elder community in Thailand - This step was to study the learning achievement of knowledge management for elder community in Thailand, the evaluation on behavior of basic health care of elder. The results were as follow:

1) The learning achievement of samples who studied via

knowledge management for elder community in Thailand.

The 20 samples had done pretest, study with the model of knowledge management on taking care of health, and had a posttest. The result was as follow:

TABLE III: THE LEARNING ACHIEVEMENT OF SAMPLES

\begin{tabular}{|l|c|c|c|c|c|c|}
\hline & $\mathrm{N}$ & Mean & SD & df & $\mathrm{t}$ & Sig. \\
\hline Pretest score & 20 & 6.85 & 1.50 & \multirow{2}{*}{19.00} & 13.03 & $\begin{array}{c}000 \\
* *\end{array}$ \\
\hline Posttest score & 20 & 11.00 & 0.86 & & & \\
\hline$* * \mathrm{p}<.01$
\end{tabular}

From Table III, the average pretest score of the samples was 6.85 and the posttest score was 11.00 . The data analysis found that the posttest score was significantly higher than pretest score at the level of .01 ( $\mathrm{t}$-test=13.03)
2) The result of behavioral evaluation on basic health care of the 20 samples on exercise, having meals, and mind approach was shown in Table IV.

TABLE IV: THE RESUlt OF BEHAVIORAL EVALUATION ON BASIC HEALTH CARE OF THE SAMPLES

\begin{tabular}{|l|l|l|}
\hline \multicolumn{2}{|c|}{ Before } & After \\
\hline Exercising & & \\
\hline Checking up & 3.75 & 4.75 \\
\hline Sleeping & 3.70 & 4.75 \\
\hline Having meals on time & 3.80 & 4.85 \\
\hline Having 3 meals a day & 3.95 & 4.70 \\
\hline Having 5 group meals & 3.85 & 4.55 \\
\hline Drinking water 6-8 glass a day & 3.99 & 4.40 \\
\hline Pills on time & 3.80 & 4.60 \\
\hline Communicate with community members & 4.15 & 4.65 \\
\hline Sharing experience with community members & 3.95 & 4.55 \\
\hline Participate activities with community members & 3.95 & 4.65 \\
\hline Relaxation to redude stress & 3.95 & 4.80 \\
\hline Total & 3.90 & 4.60 \\
\hline
\end{tabular}

From Table IV the behavior of elder in community on 
basic health care was at the level of "much".

3) The result on comparing pretest and posttest basic health care

TABLE V: THE BEHAVIOR EVALUATION ON BASIC HEALth CARE

\begin{tabular}{|l|c|c|c|c|c|c|}
\hline $\begin{array}{l}\text { Behavior of elder in } \\
\text { community on basic } \\
\text { health care }\end{array}$ & $\mathrm{N}$ & Mean & $\mathrm{SD}$ & $\mathrm{df}$ & $\mathrm{t}$ & Sig. \\
\hline $\begin{array}{l}\text { Before using } \\
\text { application }\end{array}$ & 20 & 3.89 & 0.63 & & & \\
\hline $\begin{array}{l}\text { After using } \\
\text { application }\end{array}$ & 20 & 4.66 & 0.50 & 19.00 & 18.29 & $000 *$ \\
\hline & $* 05$
\end{tabular}

From Table V, the behavior evaluation on basic health care before participating the activity was at 3.89 and after participating the activity was at 4.66 . The posttest score on basic health care was significantly higher at the level of .05 (t-test=18.29)

4) The result on satisfaction of Table VI the the samples evaluation on satisfaction of the samples who studied with the model of knowledge management

TABLE VI: THE RESUlT ON SATISFACTION OF TABLE

\begin{tabular}{|c|c|c|c|}
\hline Evaluation on satisfaction & $\mathrm{N}$ & Mean & SD \\
\hline \multicolumn{4}{|l|}{$\begin{array}{l}\text { Media for learning management / } \\
\text { application }\end{array}$} \\
\hline $\begin{array}{l}\text { Main menu is easy to understand and easy } \\
\text { to access the information }\end{array}$ & 20 & 4.3 & 0.66 \\
\hline $\begin{array}{l}\text { Harmonization of pictures and content / } \\
\text { easy understanding presentation }\end{array}$ & 20 & 4.9 & 0.31 \\
\hline Colors and pictures & 20 & 4.25 & 0.64 \\
\hline Font size, font layout & 20 & 4.45 & 0.60 \\
\hline $\begin{array}{l}\text { Easy to access, download, upload, and save } \\
\text { data }\end{array}$ & 20 & 4.8 & 0.41 \\
\hline Mean & 20 & 4.54 & 0.59 \\
\hline \multicolumn{4}{|l|}{ Content for learning management } \\
\hline Language used & 20 & 4.25 & 0.64 \\
\hline Info-graphic & 20 & 4.65 & 0.49 \\
\hline Link to other content or related & 20 & 4.55 & 0.51 \\
\hline Media and learning resources & 20 & 4.7 & 0.47 \\
\hline Mean & 20 & 4.54 & 0.55 \\
\hline \multicolumn{4}{|l|}{ Factors related to happiness and activities } \\
\hline Communication with member community & 20 & 4.75 & 0.44 \\
\hline $\begin{array}{l}\text { Group in online social media via } \\
\text { application }\end{array}$ & 20 & 4.4 & 0.50 \\
\hline $\begin{array}{l}\text { Sharing knowledge with member } \\
\text { community }\end{array}$ & 20 & 4.6 & 0.50 \\
\hline $\begin{array}{l}\text { Cooperative in activities with member } \\
\text { community }\end{array}$ & 20 & 4.7 & 0.57 \\
\hline $\begin{array}{l}\text { Sharing experience with member } \\
\text { community }\end{array}$ & 20 & 4.45 & 0.60 \\
\hline $\begin{array}{l}\text { Diffuse information for member } \\
\text { community }\end{array}$ & 20 & 4.55 & 0.60 \\
\hline Mean & 20 & 4.58 & 0.54 \\
\hline Total average & 20 & 4.55 & 0.56 \\
\hline
\end{tabular}

From Table VI, the media for learning management / model of knowledge management had mean at 4.54, S.D. at 0.59 which was at the level of "very good" and the other approach, the media for learning management had mean at 4.54 and S.D. at 0.55 . which was at the level of "very good". The third approach, factors related to happiness and activities had mean at 4.58 , S.D. at 0.54 which was at the level of "very good" and the total average in all the approach, the mean was at 4.55 and S.D. at 0.56 which was at the level of "very good" as well.
Stage 3 - The acceptance of experts in knowledge management model for elder community in Thailand

This stage was inspected by 5 experts. The researcher presented the model of knowledge management, documentation, and approved form of corrective and appropriateness of the model

TABLE VII: THE SCORE OF ACCEPTANCE AND APPROVE THE KNOWLEDGE MANAGEMENT MODEL FOR ELDER COMMUNITY IN THAILAND BY THE EXPERTS

\begin{tabular}{|l|c|c|c|}
\hline Issues for consideration & mean & S.D. & $\begin{array}{c}\text { Level of } \\
\text { appropriate } \\
\text { ness }\end{array}$ \\
\hline $\begin{array}{l}\text { 1. The appropriateness of model } \\
\text { components }\end{array}$ & 1.00 & 0.00 & accepted \\
\hline $\begin{array}{l}\text { 2. The appropriateness of model } \\
\text { steps }\end{array}$ & 1.00 & 0.00 & accepted \\
\hline $\begin{array}{l}\text { 3. The implementation in } \\
\text { practical }\end{array}$ & 0.80 & 0.50 & accepted \\
\hline Total average & 0.86 & 0.11 & accepted \\
\hline
\end{tabular}

From Table VII, the experts considered the components of the model of knowledge management for elder community in Thailand. The knowledge management model for elder community in Thailand was approved.

\section{SUMMARY AND DISCUSSION}

The research of "A Development of Model for Knowledge Management by ICT of Elder Community in Thailand" found that Stage 1 - A study and development of knowledge management for elder community in Thailand. The research surveyed to study the access of ICT media on hygiene problem and the development of model that harmonized to Ikujiro Nonaka and Takeuchi [5] that studied the knowledge management on knowledge spiral or SECI Model. The model was applied to have 4 steps: $S$ : Socialization - the members in community should gather and use ICT for the same purpose. The members came and meet to feel for doing cooperation, $E$ : Externalization - the members of the community express the interesting issue and open mind to know each other in social network. The members connected to the network to download application for communication among members. The members shared knowledge in letters and share experience or knowledge for others, $C$ : Combination - the members of community learn the content by chatting and discuss, ask or appoint to do activities among members. The members collected knowledge, analyzed, discussed and summarized for explicit knowledge systematically, $I$ : Internalization - the members of community had passed the knowledge management and record knowledge got from the activities. The knowledge from KM activities can be used in practical for all. The activity would be circulated called knowledge spiral. The content of initial of learning would be the stimulator or knowledge sharing and leaded to an analysis and connected to the next week knowledge. The knowing of ICT use, before sharing knowledge or posted any pictures would be considered.

Stage 2 - An implementation of knowledge management for elder community in Thailand 
This research was to prove that the model of knowledge management enhance the cooperative, knowledge management, knowledge storage and confirmed that the achievement of elder was significantly higher and the result was harmonized to Nonaka and Takeuchi [6] that mentioned the knowledge diffusion in the organization and create the cycle classified into 2 types of knowledge; tacit knowledge and explicit knowledge. The relation of knowledge construction was divided into 4 steps: tacit knowledge in person, transferring knowledge to others, collecting knowledge inside and outside the person, and synthesizing to gain new knowledge. So the interpersonal interaction can help for knowledge construction. The prior knowledge was developed and the new knowledge was created continually. The knowledge was shifted to be valued resources of human.

Stage 3 - The acceptance of experts in knowledge management model for elder community in Thailand To approve the knowledge management model for elder community in Thailand, the researcher synthesized, compared surveyed, created and evaluated the quality of the model and presented all to the experts for the acceptance on knowledge management model. The result was that the experts approved the knowledge management model for elder community in Thailand and confirmed to be able to use in real situation.

\section{REFERENCES}

[1] Report of elder population survey in Thailand in B.E. 2557. National Statistical. [Online]. Available: https://www.msociety.go.th/article_attach/14494/18145.pdfreact-text: 134

[2] U. Sakao. (2016). Elder community in Thailand: Real problem of health need in elder community. [Online]. Available: https://www..worldbank.org/thailand react-text:140.go.th/

[3] Nonaka and Takeuchi, "Classic work: Theory of organizational knowledge creation Morey, Maybury and Thuraisingham," Knowledge Management: Classic and Contemporary Works, pp. 139-150, 2001.

[4] P. Vijan, Method of Knowledge Management, Facilitate Institute of Knowledge Management for Social (SKS), tathaka Press, 2005.

[5] I. Nonaka and H. Takeuchi, "The knowledge-creating company: How Japanese companies create the dynamics of innovation," New York: Oxford University Press, 1995.

[6] N. Ikujiro and T. Hirotaka, The Knowledge Creating Company, New York: Oxford University Press, 1995.

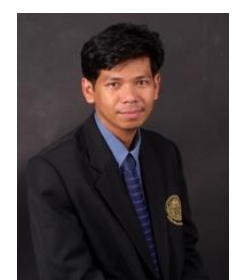

Surapon Boonlue is an assistant professor in the Department of Educational Communications and Technology, Faculty of Industrial Education and Technology, King Mongkut's University of Technology Thonburi (KMUTT), Thailand. $\mathrm{He}$ received a B.Ed. (audio visual) from Faculty of Education, Ramkhamghang University, Thailand in 1993, and an M.Ed. (educational technology) from Faculty of Education, Ramkhamghang University, Thailand in 1997. He received his Ed.D. in educational technology from Srinakharinwirot University, Bangkok, Thailand in 2007. His research interests center on distance learning, e-learning, broadcast, new media computer for education, e-learning, ICT for education, technology of education. 